(c) American Dairy Science Association, 2003.

\title{
Effects of Feeding Intensity During the Dry Period. 2. Metabolic and Hormonal Responses
}

\author{
K. Holtenius ${ }^{\star} \dagger$, S. Agenäs*, C. Delavaudł, and Y. Chilliard‡ \\ *Department of Animal Nutrition and Management, \\ †Department of Ruminant Medicine and Veterinary Epidemiology, \\ Swedish University of Agricultural Sciences, SE-750 07 Uppsala, \\ Sweden $\neq$ Unite de Recherche sur les Herbivores, \\ INRA, Theix, 63122 St-Genes-Champanelle, France
}

\begin{abstract}
The metabolic response to different feeding levels during the dry period was studied in 24 multiparous dairy cows of the Swedish Red and White breed. The cows represented two lines, selected for high or low milk fat percentage, at the same amount of energy produced in milk. The cows were fed one of three different amounts of the same total mixed diet during the dry period, starting $8 \mathrm{wk}$ prior to the expected parturition. The rations provided 71, 106, or $177 \mathrm{MJ}$ metabolizable energy per day. After parturition the cows were offered another total mixed diet ad libitum for the first 12 wk of lactation. Glucose challenges were performed 3 wk prior to and 3 wk after parturition. Prepartum the glucose clearance rate was related to feeding level. Insulin response to the glucose challenge was reduced during the postpartum period, compared to the prepartum period. During about $6 \mathrm{wk}$ prepartum, the insulin level in plasma was related to feeding level. At the sampling $3 \mathrm{wk}$ prior to parturition the plasma level of leptin also was related to the feeding level. After parturition both leptin and insulin were reduced. In early lactation plasma leptin concentration was not related to adiposity as reflected by body condition scoring. It was suggested that lactation as such affected the leptin concentration in plasma.
\end{abstract}

(Key words: dry period, glucose challenge, leptin)

Abbreviation key: AUC = area under the curve, $\mathbf{C R}$ $=$ clearance rate, $\mathbf{E B}=$ energy balance, $\mathbf{G T T}=$ glucose tolerance test, $\mathbf{H}=$ high dry period ration, $\mathbf{H F I}=$ high fat indexed selection line, $\mathbf{L}=$ low dry period ration, LFI = low fat indexed selection line, $\mathbf{M}=$ medium dry period ration, $\mathbf{M E}=$ metabolizable energy.

\section{INTRODUCTION}

Inadequate feeding during the dry period has caused a variety of problems in the postparturient cow, including

Received March 25, 2002.

Accepted August 15, 2002.

Corresponding author: K. Holtenius; e-mail: Kjell.Holtenius@ huv.slu.se. metabolic diseases, susceptibility to infections, infertility, and adverse effects on milk production. A common recommendation is that the dairy producer should try to maximize DMI intake in close-up dry cows, to prepare the cow for a higher feed intake immediately after calving and, in turn, reduce metabolic disorders (Grummer, 1995). On the other hand, overfeeding during the dry period might lead to appetite depression and an increased rate of health disorders and poor milk production (Rukkwamsuk et al., 1999). There is circumstantial evidence that these negative effects are caused by extensive degradation of body tissues in the postparturient period (Rukkwamsuk et al., 1999). Relatively few studies have evaluated the effects of restricted feeding during the dry period on the health and metabolism of cattle. Holcomb et al. (2001) found no negative effects of restricted feeding except lower milk fat percentage in early lactation.

Extensive metabolic and endocrine adjustments occur during the transition from late gestation to early lactation. The insulin concentration of plasma decreases and the responsiveness of skeletal and adipose tissue to insulin is reduced (Debrass et al., 1989; Bell and Bauman 1997; Vernon and Pond, 1997; Etherton and Bauman, 1998). These adaptations may be important factors in the initiation of catabolic activities during the periparturient period (Holtenius 1993; Chilliard, 1999). The peptide leptin has a role in the regulation of feed intake, energy expenditure, reproductive function, and the immune system (Houseknecht et al., 1998; Chilliard et al., 2001). In ruminants and other animals leptin is synthesized in proportion to the overall degree of adipocity (Maffei et al., 1995; Delavaud et al., 2000, 2002; Ehrhardt et al., 2000). The plasma concentration of leptin is reduced after parturition in dairy cows, and the reduction was induced, at least partly, by postpartal negative energy balance (EB; Block et al., 2001).

The primary aim of the present study was to investigate the response of the hormones, insulin, and leptin and metabolites in blood plasma during lactation of cows assigned to different feeding levels during the dry period.

The role of leptin in regulating milk fat production has not yet been addressed. Cows selected for different milk 
fat percentage show differences in metabolism, including milk fat de novo synthesis, glucose metabolism, and lactose production and, furthermore, tendencies toward differences in ad libitum feed intake. As a first step we wanted to investigate if there were differences in the plasma leptin concentration between these two populations.

\section{MATERIALS AND METHODS}

\section{Animals}

The study was performed with 24 multiparous dairy cows of the Swedish Red and White Breed, chosen from an ongoing selection program in the dairy herds at the Swedish University of Agricultural Sciences. In this program the cows are bred with sires that have index for high (HFI) or low (LFI) milk fat percentage at the same amount of energy produced in milk (Jansson, 1993; Åkerlind et al., 1999).

\section{Management and Experimental Design}

The cows were housed in individual tie stalls with straw and sawdust bedding throughout the experiment. Daily rations of TMR were divided into three portions, fed at 0500,1400 , and $1800 \mathrm{~h}$, administering 30,30 , and $40 \%$ of the daily ration, respectively. Feed refusals were collected once a day. Drinking water was available in automatic water bowls, and the cows had free access to saltlicks. Milking was performed twice a day at 0515 and $1545 \mathrm{~h}$ in a milking parlor. The cows were dried off from the lactation preceding this trial, approximately $10 \mathrm{wk}$ before the predicted date of parturition. They were then introduced to the experimental diets $8 \mathrm{wk}$ before parturition was expected. Four cows from each selection line were allocated to each of the three dietary treatments. The treatments consisted of 6,9 , or $14.5 \mathrm{~kg} \mathrm{DM}$ of a dry period TMR mix, providing 71, 106, or $177 \mathrm{MJ}$ metabolizable energy (ME) per day. The diets provided in average 75,110 , and $178 \%$ of the energy requirements for maintenance and pregnancy according to the Swedish feeding recommendations (Spörndly, 1999). These dietary treatments are referred to as low $(\mathbf{L})$, medium $(\mathbf{M})$, and high (H) rations. The dry period TMR had the following composition: DM, $550 \mathrm{~g} / \mathrm{kg}$; $\mathrm{ME}, 11.8 \mathrm{MJ} / \mathrm{kg} \mathrm{DM}$; and $\mathrm{AA}$ absorbed in the small intestine, $7.4 \mathrm{~g} / \mathrm{MJ}$ of ME. After parturition, all cows were fed another TMR mix ad libitum during the rest of the experimental period of $12 \mathrm{wk}$. The TMR fed during lactation had the following composition: DM, $504 \mathrm{~g} / \mathrm{kg}$; ME, $12.2 \mathrm{MJ} / \mathrm{kg} \mathrm{DM}$; and AA absorbed in the small intestine, $7.6 \mathrm{~g} / \mathrm{MJ}$ of ME. A detailed description of the composition of the TMR feeds was reported by Agenäs et al. (2003). The experimental design and all handling of the animals were approved by the Uppsala Local Ethics Committee.

\section{Blood and Milk Sample Collection}

Blood. Blood samples were collected into evacuated tubes containing sodium heparin as anti-coagulant (Venoject, Terumo, Leuven, Belgium). Blood was taken from the coccygeal vessel, weekly from 8 wk prior to the predicted parturition date until 12 -wk postpartum. The samples were taken at approximately the same time of the day (between 1000 and $1100 \mathrm{~h}$ ) and kept on ice until centrifuged (10 min at $1800 \times g$ ) within 45 min of sampling. The plasma samples were stored at $-20^{\circ} \mathrm{C}$ until analysis. The radioimmunoassay technique was used for analysis of insulin (RIA 100; Pharmacia and Upjohn Diagnostics AB, Uppsala, Sweden). Enzymatic determinations were used for glucose (Peridochrom Glucose, Boehringer Mannheim, gmbH Diagnostica, Mannheim, Germany), NEFA (NEFA C; Wako Pure Chemical Industries Ltd., Richmond, VA), BHBA (Sigma Diagnostics, St. Louis, MO), and urea (Unimate 5 urea; La Roche AG, Basel, Switzerland). The leptin content of blood plasma was analyzed in samples collected 8 and 3 wk before parturition, and 1, 3, and $12 \mathrm{wk}$ after parturition, with an ovine specific RIA-method validated and evaluated for bovine leptin (Delavaud et al., 2000; 2002). Glucose tolerance tests (GTT) were performed $3 \mathrm{wk}$ prior to the predicted parturition and 3 wk after parturition. Cows were fasted $1 \mathrm{~h}$ before and during the GTT. At least 30 min prior to the GTT a catheter was inserted into one of the jugular veins. To avoid clotting, the catheter and tubing were coated with sodium heparin. Blood was collected $-15,-5,4,8,12,18,25,36,45$, and 60 min relative to infusion of $150 \mathrm{mg}$ glucose $(50 \% \mathrm{wt} / \mathrm{vol} / \mathrm{kg} \mathrm{BW})$. The infusion time of the glucose solution was approximately $8 \mathrm{~min}$. When the infusion was complete, the catheter was flushed three times with $10 \mathrm{ml}$ of saline. The glucose tolerance test measurements included basal levels of glucose and insulin, relative glucose clearance rate $(\mathbf{C R})$, insulin peak concentration, and area under the curve (AUC). The relative glucose clearance rate was determined assuming first order kinetics using the model $G_{t}$ $=\mathrm{G}_{0} \cdot \mathrm{e}^{-\mathrm{tCR}}$. The glucose data $(\mathrm{G})$ obtained between time (t) 4 and 32 min post infusion corrected for the basal glucose level were used. Data from 45 and 60 min post infusion were excluded since negative values appeared. AUC was calculated as the insulin increment above basal level during the $60 \mathrm{~min}$ following the glucose infusion.

Milk. Milk yield was recorded daily, milk samples for analysis of milk composition were obtained at evening and morning milking twice per week. Furthermore, the concentration of progesterone in milk, collected by hand striping after finishing machine milking, was measured 
Table 1. Least squares means (LSM) and standard errors (SE) and F-tests of fixed effects included in the model for plasma hormone and metabolite concentrations from cows offered three different levels of a TMR during the dry period, sampled weekly from 8 wk before until 12 wk after parturition. Fixed effects are treatment (T), selection line (SL), time, and the interaction between $\mathrm{T} \times$ time.

\begin{tabular}{|c|c|c|c|c|c|c|c|c|}
\hline & Time (wk) & \multicolumn{3}{|c|}{ Treatment $^{1}(\mathrm{LSM} \pm$ Std Error $)$} & \multicolumn{4}{|c|}{ Fixed effects $P<$} \\
\hline Leptin $^{2}, \mathrm{ng} / \mathrm{ml}$ & $\begin{array}{r}-8 \\
-3 \\
1 \\
3 \\
12\end{array}$ & $\begin{array}{l}3.97 \pm 0.49 \\
4.56 \pm 0.49 \\
3.42 \pm 0.52 \\
3.71 \pm 0.52 \\
3.97 \pm 0.49\end{array}$ & $\begin{array}{l}4.65 \pm 0.49 \\
5.83 \pm 0.49 \\
3.05 \pm 0.49 \\
3.95 \pm 0.49 \\
3.19 \pm 0.52\end{array}$ & $\begin{array}{l}5.02 \pm 0.57 \\
7.91 \pm 0.60 \\
3.78 \pm 0.53 \\
3.47 \pm 0.53 \\
3.81 \pm 0.53\end{array}$ & 0.17 & 0.08 & 0.001 & 0.01 \\
\hline Insulin, $\mu \mathrm{U} / \mathrm{ml}$ & $\begin{array}{l}-8 \text { to }-5 \\
-4 \text { to }-1 \\
1 \text { to } 4 \\
5 \text { to } 8 \\
9 \text { to } 12\end{array}$ & $\begin{array}{l}9.12 \pm 1.18 \\
7.33 \pm 1.18 \\
4.50 \pm 0.83 \\
5.82 \pm 0.83 \\
5.89 \pm 0.88\end{array}$ & $\begin{array}{r}9.80 \pm 1.18 \\
10.41 \pm 1.18 \\
4.59 \pm 0.83 \\
6.17 \pm 0.83 \\
8.26 \pm 0.94\end{array}$ & $\begin{array}{r}16.22 \pm 1.18 \\
18.52 \pm 1.26 \\
5.23 \pm 0.89 \\
5.77 \pm 0.89 \\
6.97 \pm 0.89\end{array}$ & 0.001 & 0.17 & 0.001 & 0.001 \\
\hline Glucose, mmol/L & $\begin{array}{l}-8 \text { to }-5 \\
-4 \text { to }-1 \\
1 \text { to } 4 \\
5 \text { to } 8 \\
9 \text { to } 12\end{array}$ & $\begin{array}{l}2.83 \pm 0.06 \\
2.80 \pm 0.06 \\
2.46 \pm 0.12 \\
2.78 \pm 0.12 \\
2.87 \pm 0.13\end{array}$ & $\begin{array}{l}2.88 \pm 0.06 \\
2.95 \pm 0.06 \\
2.57 \pm 0.12 \\
2.84 \pm 0.12 \\
3.39 \pm 0.13\end{array}$ & $\begin{array}{l}3.01 \pm 0.06 \\
3.16 \pm 0.06 \\
2.89 \pm 0.13 \\
2.83 \pm 0.13 \\
3.01 \pm 0.13\end{array}$ & 0.01 & 0.61 & 0.001 & 0.09 \\
\hline Urea, mmol/L & $\begin{array}{l}-8 \text { to }-5 \\
-4 \text { to }-1 \\
1 \text { to } 4 \\
5 \text { to } 8 \\
9 \text { to } 12\end{array}$ & $\begin{array}{l}5.18 \pm 0.25 \\
5.43 \pm 0.25 \\
4.55 \pm 0.30 \\
5.49 \pm 0.30 \\
5.86 \pm 0.33\end{array}$ & $\begin{array}{l}5.65 \pm 0.25 \\
5.65 \pm 0.25 \\
4.93 \pm 0.30 \\
5.97 \pm 0.30 \\
6.19 \pm 0.33\end{array}$ & $\begin{array}{l}5.85 \pm 0.25 \\
5.80 \pm 0.26 \\
4.31 \pm 0.32 \\
5.29 \pm 0.32 \\
5.49 \pm 0.32\end{array}$ & 0.23 & 0.47 & 0.001 & 0.70 \\
\hline BHBA, mmol/L & $\begin{array}{l}-8 \text { to }-5 \\
-4 \text { to }-1 \\
1 \text { to } 4 \\
5 \text { to } 8 \\
9 \text { to } 12\end{array}$ & $\begin{array}{l}1.20 \pm 0.06 \\
1.00 \pm 0.06 \\
1.09 \pm 0.15 \\
0.15 \pm 0.15 \\
0.97 \pm 0.18\end{array}$ & $\begin{array}{l}1.35 \pm 0.06 \\
1.31 \pm 0.06 \\
1.49 \pm 0.15 \\
1.07 \pm 0.15 \\
0.70 \pm 0.17\end{array}$ & $\begin{array}{l}1.30 \pm 0.06 \\
1.09 \pm 0.07 \\
1.43 \pm 0.16 \\
1.26 \pm 0.16 \\
1.09 \pm 0.16\end{array}$ & 0.21 & 0.15 & 0.01 & 0.30 \\
\hline
\end{tabular}

${ }^{1}$ The treatments consisted of $6(\mathrm{~L}), 9(\mathrm{M})$, or $14.5 \mathrm{~kg} \mathrm{DM}(\mathrm{H})$ of a dry period TMR mix.

${ }^{2}$ Analysis only performed $-8,-3,1,3$, and 8 wk relative parturition.

twice weekly with a commercial RIA (Coat-A-Count, DCP Scandinavia), to 12 wk postpartum to monitor the onset of a normal cyclic activity.

\section{Statistical Analyses}

Analysis of variance were performed on all data using PROC MIXED (SAS, 1996). Least squares means were compared with comparison-wise error rate after significant F-tests. LSD-values were based on calculations with $t_{0.975}$. The ANOVA of plasma metabolites and hormones was performed on mean values, each representing a 4wk interval. The analyses of leptin and the data from the glucose challenge experiment were performed on individual values. Fixed effects of treatment, selection line (line), and time and their interactions were included in the model. Furthermore, the time factor was divided into two classes, defining data as before or after parturition (period). The model used different variances between subjects for the two period classes and different autoregressive covariance structure for the within subject variations. Non-significant interactions were excluded from the model for each parameter tested, except for the interaction between treatment and period that was included to provide least square means for each treatment. The degrees of freedom were approximated with Satterthwaits method. Analyses of differences between treatments in progesterone and in DMI before and after parturition were performed without the fixed effect of time (Model 2). One animal was excluded from the experiment 6 wk after parturition for reasons not related to the experiment. Values shown in the text are least square means \pm standard error of mean unless otherwise stated. 


\section{Model 1.}

PROC MIXED;

classes T SL time id period;

MODEL $=\mathrm{T}$ SL time $\mathrm{T} \times \mathrm{SL} \mathrm{T} \times$ time $\mathrm{SL} \times$ time $/ \mathrm{DDFM}=\mathrm{SAT}$;

REPEATED/SUB $=$ ID $(\mathrm{T} \times \mathrm{SL}) \mathrm{TYPE}=\mathrm{AR}(1) \mathrm{GROUP}=$ PERIOD;

\section{Model 2.}

PROC MIXED;

classes T SL id;

model: $\quad \mathrm{T}$ SL $\mathrm{T} \times \mathrm{SL}$;

T: dietary treatment (High, Normal, Low)

SL: $\quad$ selection line (HFI, LFI)

time: $\quad 4$-wk intervals $(1,2,3,4,5)$ for plasma metabolites and insulin, 5 points of time for Leptin.

period: before or after parturition

\section{RESULTS}

\section{Feed Intake and Production Response}

The composition of the feeds used in this study, as well as the effect of treatment and selection line on DMI and milk yield and their effects on milk composition are reported in detail by Agenäs et al. (2003). There were significant $(P<0.001)$ differences in the mean DMI during the dry period. The DMI were $5.9,9.0$, and $13.3 \mathrm{~kg} / \mathrm{d}$ for the $\mathrm{L}, \mathrm{M}$, and $\mathrm{H}(\mathrm{SE}=0.2 \mathrm{~kg} / \mathrm{d})$ treatments, respectively. The average DMI during dry period did not significantly influence voluntary DMI during the first $12 \mathrm{wk}$ of the lactation $(P=0.23)$. The DMI during the first $12 \mathrm{wk}$ of the lactation were $22.4,20.0$, and $20.1 \mathrm{~kg} / \mathrm{d}(\mathrm{SE}=0.2 \mathrm{~kg} /$ d) for the L, M, and $\mathrm{H}$ treatments, respectively. The average milk yield during the first 12 wk of lactation were $40.9,37.9$, and $39.1(\mathrm{SE}=1.3) \mathrm{kg} / \mathrm{d}$ energy-corrected milk for the $\mathrm{L}, \mathrm{M}$, and $\mathrm{H}$ treatments, respectively, and these values did not differ significantly from each other.

\section{Plasma Hormones and Metabolites}

The plasma level of leptin increased during the period from 8 to $3 \mathrm{wk}$ before parturition. (Figure 1). The increase was most marked among cows offered the $\mathrm{H}$ diet. The 1st wk after parturition the level had dropped in all treatments and remained lower than during the dry period until the last analysis, $12 \mathrm{wk}$ after parturition. There was no significant overall effect of treatment on the plasma level of leptin (Table 1), but there was an effect of time and an interaction between time and treatment. There was also an overall tendency $(P=0.076)$ for higher plasma leptin level in HFI cows. The plasma insulin concentration was significantly affected by both treatment, time, and their interaction. (Table 1). The cows offered the $\mathrm{H}$ diet had higher insulin concentrations in their plasma during the dry period than the other two treatments (Figure 1). The concentration started to decline rapidly close to parturition and went below $5 \mu \mathrm{U} /$ $\mathrm{ml}$ during the wk 1 after parturition, in all treatments. During the following weeks, the insulin concentration increased slightly. The plasma glucose level was also significantly affected by treatment, time, and their interaction (Table 1). During the dry period the cows fed the $\mathrm{H}$ diet had higher glucose concentrations than the other two groups (Figure 1). After parturition the plasma concentration fell markedly in all treatments and reached a nadir about 2 wk postpartum.

There was no significant overall effect of treatment on the plasma level of NEFA but there was an effect of time, and furthermore an interaction between time and treatment (Table 1 and Figure 1). After parturition the NEFA level rose markedly, and the increase was greatest in cows of group $\mathrm{M}$, which peaked in wk 1 after parturition, and then declined in wk 2 . In the other groups, $\mathrm{H}$ and L, NEFA remained elevated during the 1 mo of the lactation. During this period the rise was most pronounced among cows offered the $\mathrm{H}$ diet during the dry period while cows offered the L diet showed the lowest increase of all three groups. There was no significant effect of treatment on the plasma concentration of urea. There was a significant effect of time due to a reduction in the urea concentration during the first $4 \mathrm{wk}$ after parturition (Figure 1 and Table 1). The plasma concentration of BHBA showed a modest increase during the first period after parturition (Table 1 and Figure 1). There were no significant effects of selection line on the concentration of insulin, glucose, NEFA, urea, or BHBA.

\section{Glucose Tolerance Test}

The overall CR of glucose after the infusion did not differ between treatments but there was a significant interaction between time and treatment, thus cows receiving the $\mathrm{H}$ diet had a less pronounced increase in $\mathrm{CR}$ 

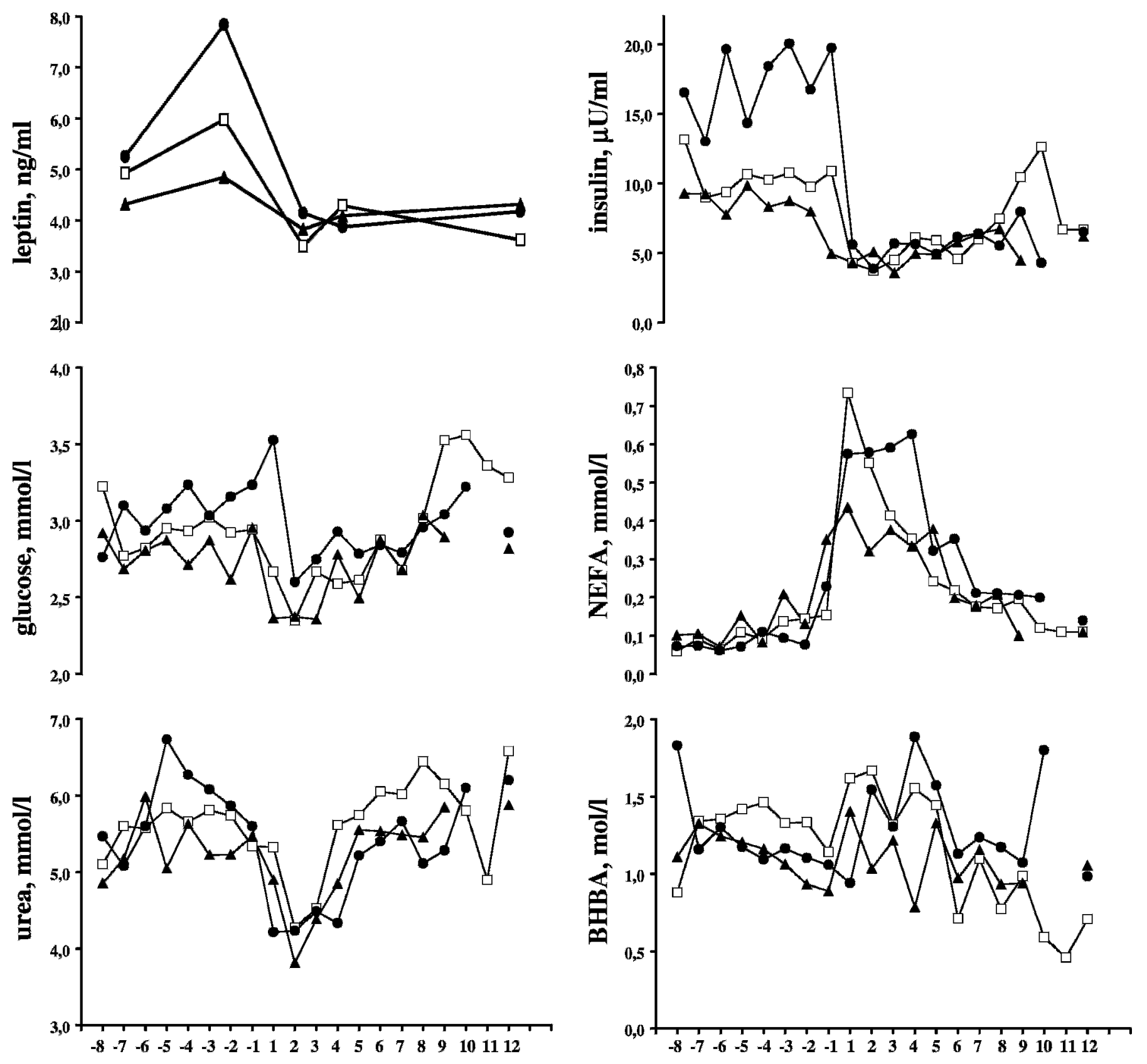

\section{week relative to parturition}

Figure 1. Changes in plasma concentrations of leptin, insulin, glucose, NEFA, urea, and BHBA. Twenty-four multiparous cows were followed during the period between $8 \mathrm{wk}$ before and $12 \mathrm{wk}$ after parturition by weekly samplings. Treatments were: 6 ( $\mathbf{\Delta}$ ), 9 ( $\square$ ), or 14.5 (-) $\mathrm{kg}$ of DM of TMR offered during the dry period. 

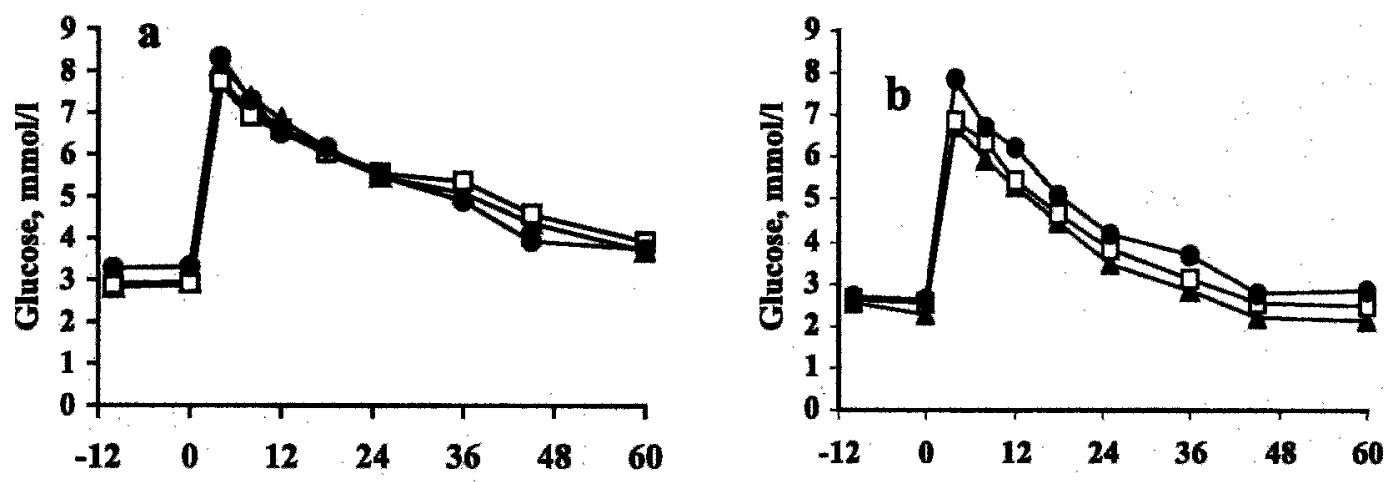

\section{time relative to glucose infusion, $\min$}

Figure 2. Response in plasma concentration of glucose after an intravenous glucose challenge performed 3 wk before (a) and 3 wk after (b) parturition. Twenty-four multiparous cows were followed during the period between 8 wk before and 12 wk after parturition by weekly samplings. Treatments were: $6(\mathbf{\Delta}), 9(\square)$, or $14.5(\bullet) \mathrm{kg}$ of DM of TMR offered during the dry period.

after parturition than those receiving $\mathrm{M}$ and $\mathrm{L}$ diets. The peak concentration of glucose following the glucose challenge was lower after parturition (Table 2 and Figure 2 ). There was also an interaction between selection line and treatment $(P<0.05)$, showing that HFI cows fed the $\mathrm{H}$ diet had higher glucose $\mathrm{CR}$ (data not shown). The plasma concentration of insulin sharply increased and then gradually decreased following intravenous glucose infusion in both prepartum and postpartum GTT (Figure 3 ). The response expressed as insulin AUC and insulin peak level was significantly higher during the prepartum period compared to the postpartum period (Table 2). There was no significant effect of dry period intake on the insulin response $(P=0.11)$, although the prepartum peak of insulin following the glucose infusion was numerically higher in cows offered the $\mathrm{H}$-diet. There was no difference in insulin AUC or insulin peak level between the selection lines.

\section{Progesterone}

Cows fed the high feeding level during the dry period had a long interval, $52 \mathrm{~d}$, from parturition to normal cyclicity according to the milk progesterone profiles. The corresponding values for the medium and low diets were 29 and $35 \mathrm{~d}$, respectively. However, the effect of treatment was not significant $(P=0.12)$. There was no significant effect of selection line on time from parturition to normal cyclicity.

\section{DISCUSSION}

\section{Preparturient Effects}

The release of leptin in plasma is increased by adipocyte hypertrophy and overfeeding in monogastric (Maffei et al., 1995) as well as in nonpregnant nonlactating ruminant (Chilliard et al., 2001) species. In the present study the $\mathrm{H}$ cows gained in body condition during the dry period while the $\mathrm{M}$ cows maintained and the L cows lost body condition during the same period (Agenäs et al., 2003). The leptin level in plasma measured 3 wk prior to parturition probably reflected differences in both $\mathrm{EB}$ and BCS between the treatments. The markedly higher plasma insulin concentration in prepartum $\mathrm{H}$ cows, compared to $\mathrm{M}$ and L cows, agrees with previous studies (Kunz et al., 1985; Grum et al., 1996) and reflects positive EB. There is convincing evidence that insulin has long term stimulating effects on leptin secretion in human (Malmström et al., 1996; Boden et al., 1997) and on leptin production in vitro by ruminant adipose tissue (Chilliard et al., 2001). It is thus possible that the elevated insulin concentration in $\mathrm{H}$ cows prepartum also contributed to the high leptin level. But leptin also exerts inhibiting effects on insulin release in mice. If a similar effect is prevailing in cattle, it might have prevented an even higher insulin release during the dry period (Kulkarni et al., 1997; Harris, 1998). There was a small effect of diet on the prepartum plasma concentration of glucose, urea, BHBA, and NEFA. These results are in agreement with those of others, reporting negligible effects of feeding level during the dry period on prepartum metabolic profile (Kunz et al., 1985; Rukkwamsuk et al., 1999a). Nevertheless, differences between the treatments were found in the glucose tolerance test performed 3 wk prior to expected parturition. The cows assigned to the $\mathrm{H}$ diet responded with a higher insulin peak than those assigned to the other two diets. This agrees with the studies of McCann and Reimers (1986) showing that obese heifers responded with greater glucose-induced secretion of insulin than lean heifers. We found a marked effect of treatment on 

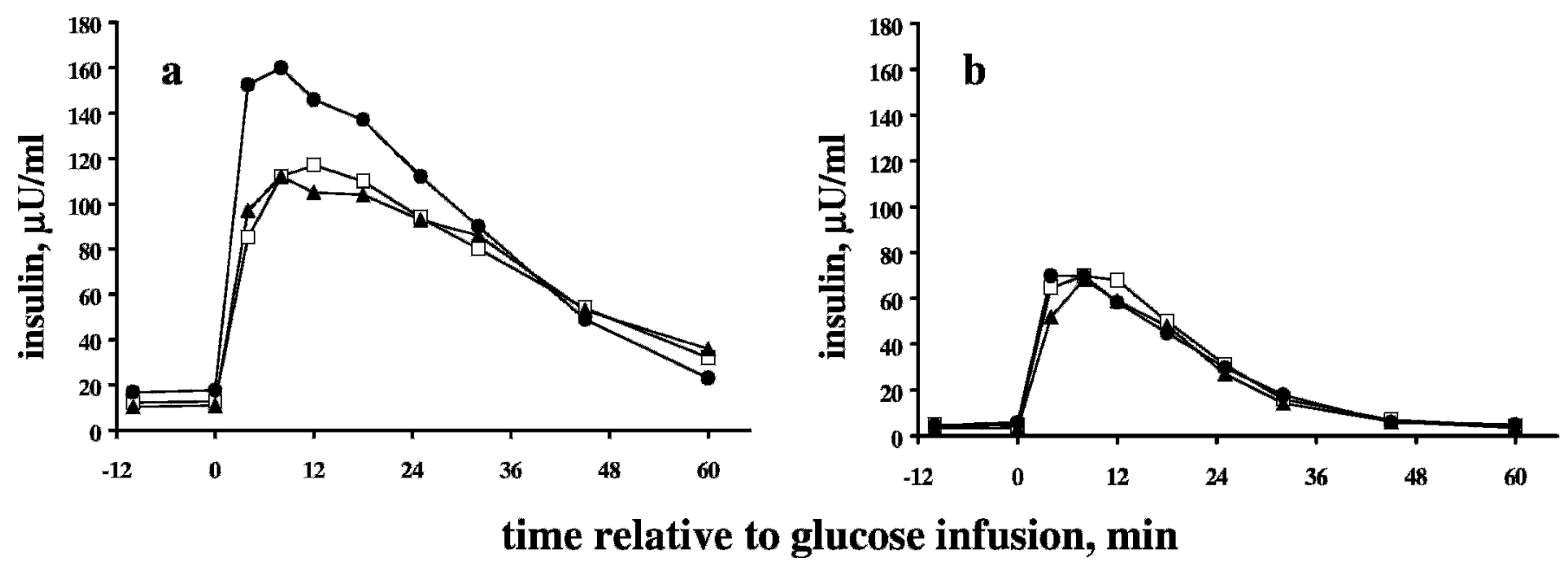

Figure 3. Response in plasma concentration of insulin after an intravenous glucose challenge performed 3 wk before (a) and 3 wk after (b) parturition. Twenty-four multiparous cows were followed during the period between 8 wk before and 12 wk after parturition by weekly samplings. Treatments were: $6(\mathbf{\Delta}), 9(\square)$, or $14.5(\bullet) \mathrm{kg}$ of DM of TMR offered during the dry period.

CR prepartum. Cows that received the more intensive feeding may have had a higher gastrointestinal uptake of glucose precursors, like propionate and glucogenic AA, and thus a higher hepatic rate of glucose synthesis. It is reasonable to assume that a significant part of the prepartum variation in observed glucose CR was influenced by the availability of glucogenic substrates from feed.

\section{Postparturient Effects}

The leptin concentration in plasma was reduced after parturition. It appears that EB is one factor responsible for the regulation of the plasma leptin in postparturient dairy cows, since nonlactating cows in positive EB had a higher leptin concentration than lactating cows in negative balance (Block et al., 2001). However, in the present study leptin remained low 12 wk after parturition even in $\mathrm{L}$ and $\mathrm{M}$ cows although they had reached positive EB (Agenäs et al., 2003). An effect of lactation per se on leptin secretion could not be excluded. In dry Holstein cows the leptin concentration in plasma was related to body fatness as determined by adipocyte size (Chilliard et al., 2001). The cows in the present study had a large variation in BSC the week after parturition due to different feeding intensities during the dry period (Agenäs et al., 2003). However the leptin concentration in plasma was not related to BCS (data not shown). Thus it is suggested that leptin is not related to body condition in postparturient cows.

Block et al. (2001) found that leptin correlated significantly to insulin, NEFA, GH, and glucose in postpartal cows with both positive and negative EB. It was suggested that these components could mediate the effect

Table 2. Least square means (LSM) and standard errors (SE) and $F$-tests of fixed effects included in the model for plasma glucose and insulin responses to glucose challenge in cows $3 \mathrm{wk}$ before calculated and $3 \mathrm{wk}$ after parturition in cows offered three different levels of a TMR during the dry period. Fixed effects are treatment (T), selection line (SL), time and the interaction between $\mathrm{T} \times$ time.

\begin{tabular}{|c|c|c|c|c|c|c|c|c|}
\hline & Time (wk) & \multicolumn{3}{|c|}{ Treatment $^{1}(\mathrm{LSM} \pm \mathrm{SE})$} & \multicolumn{4}{|c|}{ Fixed effects, $P<$} \\
\hline Glucose $\mathrm{CR}^{2}, \% / \mathrm{min}$ & -3 & $2.44 \pm 0.20$ & $2.83 \pm 0.20$ & $4.18 \pm 0.24$ & 0.64 & 0.21 & 0.001 & 0.005 \\
\hline $\mathrm{AUC}^{3}$, Insulin, $\mu \mathrm{U} / \mathrm{mL} \cdot \mathrm{h}$ & $\begin{array}{r}-3 \\
3\end{array}$ & $\begin{array}{l}65.38 \pm 7.64 \\
22.55 \pm 3.60\end{array}$ & $\begin{array}{l}63.5 \pm 7.64 \\
24.1 \pm 3.60\end{array}$ & $\begin{array}{l}73.08 \pm 8.82 \\
21.89 \pm 4.16\end{array}$ & 0.82 & 0.74 & 0.001 & 0.65 \\
\hline
\end{tabular}

${ }^{1}$ The treatments consisted of 6 (Low), 9 (Medium), or $14.5 \mathrm{~kg}$ DM (High) of a dry period TMR mix.

${ }^{2}$ Clearance rate.

${ }^{3}$ Area under the curve. 
of EB on leptin synthesis. In the present study, plasma insulin was low during the postparturient period, which may have contributed to the low level of leptin. However, both NEFA and glucose showed a significant variation during the postparturient period and did not correlate to leptin (data not shown). This observation does not support the suggestion above that NEFA or glucose might regulate leptin synthesis.

The NEFA concentration in plasma during the postparturient period reflects the rate of lipolysis (Pullen et al., 1989) or lipomobilization, i.e., the balance between lipolysis and re-esterification of fatty acids (Chilliard, 1999). The rise in NEFA concentration was observed in all three treatments for several weeks after parturition and was most extensive in cows offered the $\mathrm{H}$ diet during the dry period, while the increase was least extensive in cows offered the $L$ diet. This indicates that the magnitude of mobilized adipose tissue the period after parturition was inversely related to the DMI during the prepartum period. In line with these results Holcomb et al. (2001) reported that plasma NEFA was lower in cows for which feed was restricted prepartum.

The change in BW during the 2 mo following parturition was inversely related to the level of DMI during the dry period. The week after parturition the BW was 592 $(\mathrm{SD}=43), 592(\mathrm{SD}=51)$, and $643(\mathrm{SD}=82) \mathrm{kg}$ in $\mathrm{L}, \mathrm{M}$, and $\mathrm{H}$ cows, respectively $(\mathrm{SE}=22 \mathrm{~kg})$. Eight weeks after parturition the $\mathrm{BW}$ was $605(\mathrm{SD}=53), 588(\mathrm{SD}=56)$, and $607(\mathrm{SD}=79) \mathrm{kg}$. The changes in BCS showed a similar pattern. The week after parturition the BCS, on a scale 1 to 5 , was $2.6,3.6$, and 4.2 in $\mathrm{L}, \mathrm{M}$, and $\mathrm{H}$ cows, respectively $(\mathrm{SE}=0.27)$. Six weeks after parturition the BSC had changed to 2.8, 3.3, and 3.6 ( $\mathrm{SE}=0.28)$. However, there was no significant treatment effect on the EB during the first 4 wk postpartum (Agenäs et al., 2003). These intriguing results thus indicate that the $\mathrm{H}$ cows lost more body condition than the M and L cows, although there was no significant difference in EB. As fat ewes lost more body fat than lean ewes receiving the same amount of feed energy per kilogram of $\mathrm{BW}^{0.75}$ (Chilliard et al., 2000), it can be suggested that fat animals were less efficient and wasted more energy. It has recently been demonstrated that leptin triggered increased lipolysis, metabolic rate and energy wasting in rats (Reidy and Weber, 2002). In mice that previously had chronically elevated levels of circulating leptin, these effects were maintained even when leptin was absent (Steinberg et al., 2002). It can thus be speculated that the increased losses in body condition in $\mathrm{H}$ cows was an effect of the hyperleptinemia prepartum.

It is well documented that humans with insulin resistance have an increased rate of lipolysis even during full nutritional support (Brandi et al., 1990; Tappy et al., 2000). In ruminants, early lactation is characterized by a moderate degree of insulin resistance in adipose tissue and muscles, thereby promoting the mobilization of NEFA and AA and the sparing of glucose (Bell, 1995). The NEFA in turn contributes to the development of insulin resistance by suppression of glucose uptake in adipose tissue and muscles (Boden, 2001). In the present study both the insulin AUC and the insulin peak response following GTT were significantly reduced postpartum in all treatments. This mechanism is probably also part of the metabolic adaptations to the demands during early lactation. The $\mathrm{CR}$ of glucose in $\mathrm{H}$ cows following the GTT performed $3 \mathrm{wk}$ after parturition were about $20 \%$ lower than in $\mathrm{L}$ and $\mathrm{M}$ cows. There were no significant treatment effects on postparturient feed intake or milk production. It is therefore reasonable to assume that the uptake of glucose precursors from the gastrointestinal tract, and the mammary drain of glucose were of similar magnitude and thus did not give rise to differences in response to the GTT. We therefore suggest that the lower $\mathrm{CR}$ in $\mathrm{H}$ cows reflects a greater degree of insulin resistance which gave rise to more pronounced net lipolysis from the adipocytes. This also offers a possible explanation for the higher concentration of NEFA and the more pronounced loss of BCS.

According to McClure (1994), resumption of estrus within $30 \mathrm{~d}$ postpartum is considered optimal. In the present study, the resumption of estrus in $\mathrm{H}$ cows occurred in average $52 \mathrm{~d}$ postpartum. Corresponding figures for the L and M cows were 35 and $29 \mathrm{~d}$, respectively. Although the length of the postpartum anestrus was numerically longer among $\mathrm{H}$ cows, the limited number of animals does not permit any interpretation of this observation.

\section{Selection Lines}

The HFI cows tended to have a higher overall concentration of leptin in plasma than LFI cows. The higher leptin concentration does not appear to be related to differences in adiposity since the BCS was similar in both groups (Agenäs et al., 2003). This indication-that leptin is related to milk composition-requires further studies. Our previous observation that the HFI cows had greater glucose CR, indicating a higher uptake of glucose in insulin-sensitive tissues (Akerlind et al., 1999) was here confirmed only in HFI cows receiving the $\mathrm{H}$ diet.

\section{Implications}

Based on these results, it can be suggested that cows that are fed to reduce body condition score during the dry period may perform well after parturition if they are offered a high-quality lactation TMR ad libitum. On the other hand cows fed to gain body condition during the 
dry period may mobilize more of their body resources and have a prolonged postpartal negative EB.

\section{ACKNOWLEDGMENTS}

The authors thank Hans Gustafsson for evaluating the milk progesterone profiles. Financial support from the Swedish Council for Forestry and Agricultural Research (No. 30.0590/98) and the Swedish Farmers Foundation for Agricultural Research (No. 9930028 and 9930044).

\section{REFERENCES}

Agenäs, S., E. Burstedt, and K. Holtenius, 2003. Effects of feeding intensity during the dry period. 1 . Feed intake and milk production. J. Dairy Sci. 86:870-882.

Åkerlind, M., K. Holtenius, J. Bertilsson, and M. Emanuelson. 1999. Effect of selection for high or low milk fat percentage in dairy cows on feed intake and milk composition, Livest. Prod. Sci.59:1-11.

Bell, A., and D. E. Bauman. 1997. Adaptations of glucose metabolism during pregnancy and lactation. J. Mammary Gland Biol. Neoplasia. 2:265-278.

Block, S. S., W. R. Butler, R. A. Ehrhardt, A. W. Bell, M. E. Van Amburgh, and Y. R. Boisclair. 2001. Decreased concentration of plasma leptin in periparturient dairy cows is caused by negative energy balance. J. Endocrinol. 171:339-348.

Boden, G., X. Chen, J. W. Kolaczynski, and M. Polansky. 1997. Effects of prolonged hyperinsulinemia on serum leptin in normal human subjects. J. Clin. Invest. 100:1107-1113.

Brandi, L. S., M. Frediani, M. Oleggini, F. Mosca, M. Cerri, C. Boni, N. Pecori, G. Buzzigoli, and E. Ferrannini, 2000. Insulin resistance after surgery: normalization by insulin treatment. Clin. Sci. (Lond). $7: 443-450$

Chilliard, Y., 1999. Metabolic adaptations and nutrient partitioning in the lactating animal. Pages 503-552 in Biology of Lactation. J. Martinet, L. M. Houdebine, and H. H. Head (ed.), Collection Mieux Comprendre, INRA Editions Paris.

Chilliard, Y., A. Ferlay, Y. Faulconnier, M. Bonnet, J. Rouel, and F. Bocquier. 2000. Adipose tissue metabolism and its role in adaptations to undernutrition in ruminants. Proc. of the Nutr. Soc. 59:127-134.

Chilliard, Y., M. Bonnet, C. Delavaud, Y. Faulconnier, C. Lerou, J. Djiane, and F. Bocquier. 2001. Review: Leptin in ruminants. Gene expression in adipose tissue and mammary gland, and regulation of plasma concentration. Domest. Anim. Endocrinol. 21:271-295.

Debras, E., J. Grizard, E. Aina, S. Tesseraud, C. Champredon, and M. Arnal. 1989. Insulin sensitivity and responsiveness during lactation and dry period in goats. Am. J. Physiol. 256:E295-302.

Delavaud, C., A. Ferlay, Y. Faulconnier, F. Bocquier, G. Kann, and Y. Chilliard. 2002. Plasma leptin concentration in adult cattle: Effects of breed, adiposity, feeding level and meal intake. J. Anim. Sci. 80:1317-1328.

Delavaud, C., F. Bocquier, Y. Chilliard, D. H. Keisler, A. Gertler, and G. Kann. 2000. Plasma leptin determination in ruminants: Effect of nutritional status and body fatness on plasma leptin concentration assessed by a specific RIA in sheep. J. Enodcrinol. 165:519-526.

Ehrhardt, R. A., R. M. Slepetis, J. Siegal-Willott, M. E. Van Amburgh, A. W. Bell, and Y. R. Boisclair. 2000. Development of a specific radioimmunoassay to measure physiological changes of circulating leptin in cattle and sheep. J. Endocrinol. 166:519-528.

Etherton, T. E., and D. E. Bauman 1998. Biology of somatotropin in growth and lactation of domestic animals. Physiol. Rev. 78:7745-7761.
Grum, D. E., J. K. Drackley, L. R. Hansen, and J. D. Cremin Jr. 1996. Production, digestion, and hepatic lipid metabolism of dairy cows fed increased energy from fat or concentrate. J. Dairy Sci. 79:1836-1849

Grummer, R. 1995. Impact of changes in organic nutrient metabolism on feeding the transition dairy cow. J. Anim. Sci. 73:2820-2833.

Harris, R. B., J. Zhou, S. M. Redmann Jr., G. N. Smagin, S. R. Smith, F. Rodgers, and J. J. Zachwieja. 1998. A leptin dose-response study in obese (ob/ob) and lean (+/?) mice. Endocrinology 139:8-19.

Holcomb, C. S., H. H. Van Horn, H. H. Head, M. B. Hall, and C. J. Wilcox. 2001. Effects of prepartum dry matter intake and forage percentage on postpartum performance of lactating dairy cows. J. Dairy Sci. 84:2051-2058.

Holtenius, P. 1993. Hormonal regulation related to the development of fatty liver and ketosis. Acta Vet. Scand. Suppl. 89:55-60.

Houseknecht, K. L., C. A. Baile, R. L. Matteri, and M. E. Spurlock. 1998. The biology of leptin: A review. J. Anim. Sci. 76:1405-1420. Havel, P. J. 2002. Control of energy homeostasis and insulin action by adipocyte hormones: leptin, acylation stimulating protein, and adiponectin. Curr. Opin. Lipidol. 13:51-59.

Jansson, L. 1993. Vad händer vid urval för lâg respektive hög mjölkfetthalt? SLU Info Rapporter, Allmänt 181 pp. N22 Uppsala, Sweden: Swedish University of Agricultural Sciences (in Swedish).

Kulkarni, R. N., Z. L. Wang, R. M. Wang, J. D. Hurley, D. M. Smith, M. A. Ghatei, D. J. Withers, J. V. Gardiner, C. J. Bailey, and S. R. Bloom. 1997. Leptin rapidly suppresses insulin release from insulinoma cells, rat and human islets and, in vivo, in mice. J. Clin. Invest. 100:2729-2736.

Kunz, P. L., J. W. Blum, I. C. Hart, H. Bickel, and J. Landis. 1985. Effects of different energy intakes before and after calving on food intake, performance, and blood hormones and metabolites in dairy cows. Anim. Prod. 40:219-231.

Maffei, M., J. Halaas, E. Ravussin, R. E. Pratley, G. H. Lee, Y. Zhang, H. Fei, S. Kim, R. Lallone, S. Ranganathan, P. A. Kern, and J. M. Friedman. 1995. Leptin levels in human and rodent: measurement of plasma leptin and ob RNA in obese and weight-reduced subjects. Nat. Med. 11:1155-1161.

Malmstrom, R., M. R. Taskinen, S. L. Karonen, and H. Yki-Jarvinen. 1996. Insulin increases plasma leptin concentrations in normal subjects and patients with NIDDM. Diabetologia. 39:993-996.

McCann, J. P., and T. J. Reimers, 1986. Effects of obesity on insulin and glucose metabolism in cyclic heifers. J. Anim. Sci. 62:772-782.

McClure, T. J. 1994. Nutritional and metabolic infertility in the cow. Oxon: Cab. International 8.

Pullen, D. L., D. L. Palmquist, and R. S. Emery. 1989. Effect of days of lactation and methionine hydroxy analog on incorporation of plasma free fatty acids into plasma triglycerides. J. Dairy Sci. 72:49-58.

Reidy, S., and J.-M. Weber. 2002. Accelerated substrate cycling: a new energy-wasting role for leptin in vivo. Am. J. Physiol. Endocrinol. Metab. 282: E312-E317.

Rukkwamsuk, T., T. A. Kruip, and T. Wensing. 1999. Relationship between overfeeding and overconditioning in the dry period and the problems of high producing dairy cows during the postparturient period. Vet. Q. 21:71-77.

SAS User's Guide. 1996. SAS/Stat Software. Changes and enhancement through release 6.12 SAS Inst., Inc., Cary, NC.

Spörndly, R. 1999. Fodertabell för idisslare. Rapport 247, Dept. of Anim. Nutr. and Management, Swedish Univ. Agric. Sci., Uppsala, Sweden (in Swedish).

Steinberg, G. R., A. Bonen, and D. Dyck. 2002. Fatty acid and triacylglycerol hydrolysis are enhanced after chronic leptin treatment in rats. Am. J. Physiol. Endocrinol. Metab. 282:E593-E600.

Tappy L., M. Berger, and M. Chiolero. 2000. Nutrition and stress Ann. Med. Interne (Paris). 151:584-593. (in French)

Vernon, R. G. C. M. Pond. 1997 Adaptations of maternal adipose tissue to lactation. J. Mammary Gland Biol. Neoplasia. 2:231-241. 